\title{
The Impacts of Covid-19 Pandemic on Socio-Economic Mobility in Indonesia
}

\begin{abstract}
Submitted 05/05/20, $1^{\text {st }}$ revision 11/06/20, $2^{\text {nd }}$ revision 01/07/20, accepted 20/07/20
Nano Prawoto ${ }^{1}$, Eko Priyo Purnomo ${ }^{2}$, Abitassha Az Zahra ${ }^{3}$

Abstract:

Purpose: The purpose of this article is to examine the impacts of the COVID-19 pandemic on social and economic mobility occurring in Indonesia. The research illustrates that the effects of the pandemic are strongly felt in mobility in the socio-economic sectors.

Design/Methodology/Approach: To give answer to the research question whether COVID19 pandemic has impact on socio-economic mobility in Indonesia, firstly, we review the literature to find out what different scholars have found in recent researches concerning this subject as well as the current issue and the methods and models used in collecting, processing, and analyzing data. The processing of the data of the above-mentioned reports has been done by SPSS software program, specifically using regression.

Findings: The possible impacts caused a decrease in socio-economic activities and reduced community income. The results of the correlation analysis showed that there was a strong relationship between a pandemic tested positive for COVID-19 and mortality rates with socio-economic conditions with an average correlation coefficient above 0.80 .

Practical Implications: This paper will provide a detail analysis of the impact of COVID-19 on socio-economic mobility, with this impact, government policies relating to human life, economic policies to increase state expenditure (government expenditure), and tax incentives must be made. Furthermore, monetary policy that can accelerate the increase in production by reducing the cost of production through the cost of capital and reduce energy prices becomes an essential choice.

Originality/Value: This research paper highlights an empirical analysis based on real data of socio economy mobility in Indonesia.
\end{abstract}

Keywords: COVID-19 Pandemic, Socio-economic mobility, correlation coefficient.

JEL codes: J4, E2O.

Paper Type: Research article.

\footnotetext{
${ }^{1}$ Universitas Muhammadiyah Yogyakarta - Indonesia, Email: nanopra@umy.ac.id

${ }^{2}$ Universitas Muhammadiyah Yogyakarta - Indonesia, Email: eko@umy.ac.id

${ }^{3}$ Universitas Muhammadiyah Yogyakarta - Indonesia Email: abitasshaa@ gmail.com
} 


\section{Introduction}

The new type of coronavirus (SARS-CoV-2) called COVID-19 originated from the city of Wuhan in China, which spread to various countries in the world was finally, on March 11, 2020, established as a pandemic by the WHO. This condition should not be underestimated because not many diseases spreading can be classified as a pandemic. Pandemic is an epidemic that has spread to several countries or continents and generally affects many people. Meanwhile, an epidemic is a term to describe the sudden increase in the number of cases of a disease in a population in a specific area.

The term pandemic is not used to indicate the severity of a disease, but only the extent of its spread. In the current case, COVID-19 becomes the first pandemic caused by a coronavirus. Before this pandemic, various influenza pandemics had occurred in the world. One of them is the swine flu breaking out in 2009. The disease occurred when a new strain of influenza (H1N1) spread across the globe.

Meanwhile, the worst case of an influenza pandemic happened during the Spanish flu pandemic in 1918, causing up to 50 million deaths worldwide. The problem of a pandemic is actually a threat to almost all countries. The threat of this pandemic cannot be denied to cause a variety of new problems in various aspects of life, such as economic and social aspects (Walmsley, Rose, and Wei, 2020; Malawani et al. 2020). The pandemic in general is not only a severe public health problem but an initial trigger for the emergence of catastrophic economic and political crises in infected countries (Bartik et al., 2020). The global health crisis caused by the outbreak of the COVID-19 virus has led many countries to adopt social distancing measures. These include shutting down public spaces, restaurants and shops, closing schools, and limiting any economic activity that leads to close physical contact between workers.

The social distancing policy makes several ways a pandemic of infectious diseases impacts the economy and the society. It is because various statements of social distancing deemed an effective means of preventing the transmission of viruses. The social distancing policy makes a negative effect on production because reducing the quantity of labour and social isolation. But, the negative impact of pandemics which is often oblivion is time and revenue expenses for patients and additional spending on patient treatment and social programs.

Therefore, in this study, we want to see the impact more deeply by the COVID-19 pandemic in two sectors, namely the economic sector and the social sector. The policy regarding social distancing has results in a decline in production. It is a new challenge for the Government to make policies that minimizing the impact on the economic and social sector. These two things are important because they are the two sectors most vulnerable to being affected by pandemics. 


\section{The Literature Review of Pandemic Impact}

\subsection{The Impact of Pandemic Diseases on Economy and Social Context}

The problem of a pandemic is actually a global threat that can occur throughout the world (Baker et al., 2020). The threat of this pandemic cannot be denied to cause a variety of new problems in various aspects of life, especially in economic aspects (Filipe, 2020; Sharif, Aloui, and Yarovaya, 2020). The pandemic indeed, in general, is not only a severe public health problem but an initial trigger for the emergence of catastrophic economic and political crises in infected countries (Carter and Anderson, 2020).

There are several ways through which a pandemic of infectious diseases impacts the economy (Ozili and Arun, 2020). The primary and indirect economic effects of the pandemics are more focussing on health policy analysis than the burden of disease (Barrot, Grassi, and Sauvagnat, 2020). The traditional approach uses details on death, mortality, and morbidity to predict potential profit loss related to death and injury (Del Rio-Chanona et al., 2020). Time and revenue expenses for patients and additional spending on patient treatment and social programs are impacted that oblivion caused the pandemics (Inoue and Todo, 2020). This conventional approach underestimates the true economic costs of epidemic diseases that are highly communicable and for which there is no vaccine such as HIV, AIDS, SARS and pandemic influenza (Alvarez, Argente, and Lippi, 2020). The pandemic pressure on economic aspects has significant impacts not only in developing countries such as those on the continents of Asia and Africa (Fernandes, 2020) but also in developed countries (Becker, 1990; Purnomo et al., 2019). It caused a shock as the impacts of the pandemic on global social and economic aspects in a country were judged faster and more severe than the global financial crisis and The Great Depression (Abodunrin and Oloye, 2020). It is certainly not surprising, considering the lockdown policy adopted by several infected countries that have made all educational institutions, commercial, sports, and religious institutions closed temporarily hence, it undoubtedly has a sustained effect on the cessation of the economic sector (Guerrieri et al., 2020).

The COVID-19 case has indeed caused quite a severe paralysis in the economic sector of the infected country (Rincón-Aznar, Mao, and Tong, 2020; Grima et al., 2020). The pandemic problems occurring in China can be a real example that the threat of a pandemic puts enormous pressure on the economic aspects. Therefore, the high financial pressure caused by the COVID-19 pandemic is not only felt by developing countries, but also by developed countries (Huang et al., 2020). The Chinese Government responded to the pandemic occurring in the country with various attempts to suppress the rapid spread of COVID-19, such as quarantine and widespread restrictions on mobility and work travel (Hien et al., 2020). The policy taken by China is indeed practised by almost all countries struggling to slow the transmission of COVID-19 disease (Ali and Alharbi, 2020). Although this policy 
has proven to be effective in suppressing the spread of COVID-19, there are some side effects, including on the world economic crisis and environmental impacts (Khoury and Karam, 2020).

Moreover, the lockdown policy adopted by the Chinese Government has another impact, which is causing new problems in unpredictable delays in the movement of the economic sector in the country (Karin et al., 2020). Thus, it has a significant reduction effect in many service sector activities (Venkates, 2020). In addition to the service sector, the industrial sector also feels a significant impact as it is related to essential facilities being closed for a long time in many countries (McKee and Stuckler, 2020). Then, in addition to the stagnation in the movement of the economic sector, the pandemic also has other adverse consequences in the socio-economic aspects, such as the emergence of direct disruption to the global supply chain, weaker demand for imported goods and services, and a broader decline in the international tourism sector and business travel (Hall, Scott, and Gössling, 2020).

Thus, the peak of the pressures causes the quite long and unpredictable economic cessation duration, increasing unemployment that becomes more vulnerable due to lack of productivity, and excessive spending on maintenance (Barua, 2020). The pandemic also not only has an impact on the economic life of a country but also puts high pressure on the social aspects of society (Chakraborty and Maity, 2020). Disruptions to the global supply chain cannot be denied due to the emergence of concerns among the public regarding their safety (Arafat et al., 2020). It is unavoidable during the pandemic because, psychologically, individuals will try to protect their respective families by various means (Raju, 2020). It then leads to panic buying (Hossain, Ferdous, and Siddiqee, 2020). However, panic buying events occurring during a pandemic vary in level based on the category of country and culture growing within the country (Kramer and Kramer, 2020). Also, there are other factors, which later become the causes of panic buying among the people, namely due to the emergence of a sense of anxiety about the uncertainty of the duration of the pandemic (Sim, Chua, Vieta, and Fernandez, 2020).

It is undeniable that one of the real effects of a pandemic outbreak is an intense psychological effect, which becomes a moral panic spreading globally and is accompanied by a feeling of stigma about the certainty of the end of the pandemic (Guan, Deng, and Zhou, 2020). Thus, in this case, the Government's role becomes crucial to reduce the level of public anxiety (Jasper and Nicomedes, 2020). The purpose of communication media is also demanded to be able to create conditions that do not provoke miss information and contribute to unnecessary public panic and produce unwanted responses (Bento et al., 2020). It is important to remember that the peak of this panic generates egoism, such as capitalist behaviour, xenophobia, and trust in every news item seen on social media (Chan et al., 2020). 


\section{Research Method}

This study used secondary data on COVID-19 conditions in Indonesia for 72 days from February 15, 2020, to April 26, 2020. The data were obtained from several sources published, such as the COVID-19 Community Mobility Reports Institute and COVID-19.go.id. In analyzing the data, the researchers utilized descriptive statistical methods and quantitative analysis with the correlation method. The descriptive statistic was employed to describe the trend of the variables studied, including the COVID-19 variable, which was the number of people positively infected with this disease and the number of deaths due to this disease, and the mobility of socio-economic activities variable included:

Retail and Recreation: It is a mobility trend for places, such as wholesale markets, food warehouses, farmers' markets, speciality food stores, drug stores, and pharmacies.

> Parks: It includes mobility trends for places, such as local parks, national parks, public beaches, marinas, dog parks, plazas, and public parks.

$>$ Transit Stations: It is a mobility trend for places, such as public transportation hubs comprising of subways, buses, and train stations.

$>$ Grocery and Pharmacy: It includes mobility trends for places like restaurants, cafes, shopping centres, theme parks, museums, libraries, and theatres.

$>$ Residential: It is a mobility trend for residence.

$>$ Workplaces: It includes mobility trends for the workplace (Guan, Deng, and Zhou, 2020).

Furthermore, the quantitative analysis used the calculation of the correlation coefficient to measure the degree of closeness stated to be very strong, strong, moderate, low, and very low between the $\mathrm{X}$ variable and the $\mathrm{Y}$ variable (Basuki and Prawoto, 2017). The analysis employed the correlation coefficient between COVID19, which was stated positively infected and death due to illness, and the variables mentioned above, such as sectors of retail and recreation, grocery and pharmacy, parks, transit stations, workplaces, and residential in Indonesia. To find the correlation coefficient between variable $\mathrm{X}$ and $\mathrm{Y}$, the following product-moment correlation formula was used (Sugiyono, 2012):

$r_{x y}=\frac{n \sum x_{t} y_{t}-\left(\sum x_{t}\right)\left(\sum y_{t}\right)}{\sqrt{\left(n \sum x_{t}^{2}-\left(x_{t}\right)^{2}\right)\left(n \sum y_{t}^{2}-\left(y_{t}\right)^{2}\right)}}$

Description:

$\mathrm{r}_{\mathrm{xy}} \quad$ : Correlation coefficient

$\Sigma \mathrm{X}$ : Variable X (Socio-Economic Mobility)

$\Sigma \mathrm{Y} \quad$ : Variable Y (COVID-19)

$\mathrm{N} \quad$ : Amount of research data 
In identifying the high and low correlation, interpretation criteria were employed, as in Table 1. Therefore, the purpose of the analysis in this article is to discover how strong the relationship between both COVID-19 pandemic level variables positively indicated (POS) and mortality rate (DEA) and the variable level of social and economic activity mobility of several sectors, such as retail and recreation (RR), grocery and pharmacy (GP), parks (PRK), transit stations (TS), workplaces (WP), and residential (RES) in Indonesia during the 72-day research period from February 15, 2020, to April 26, 2020 (Basuki and Prawoto, 2016).

Table 1. Correlation Coefficient Intervals

\begin{tabular}{|l|l|}
\hline Coefficient Interval & Relationship Level \\
\hline $0.000-0.199$ & Very Low \\
\hline $0.200-0.399$ & Low \\
\hline $0.400-0.599$ & Moderate \\
\hline $0.600-0.799$ & Strong \\
\hline $0.800-1.000$ & Very Strong \\
\hline
\end{tabular}

Source: Sugiyono, 2012.

\section{COVID-19 Pandemic Trend in Indonesia}

The COVID-19 pandemic is now a global threat. It is undeniable that the threat caused by this pandemic raises new issues in the aspects of life, specifically in economic and social aspects. The pressure caused by the COVID-19 pandemic on various economic and social activities occurs not only in the developing countries but also in developed countries. It is what makes shocks to the global economic outlook due to COVID-19 considered faster and worse than the global financial crisis and the Great Depression. This is not surprising considering the lockdown policy adopted by several infected countries has made all educational institutions, commercial, sports and spiritual institutions closed temporarily. Hence, it certainly has a sustained effect on the cessation of the economic sector (Gershon, Lipton, and Levine, 2020). Therefore, Government has the important role to make strategic plan to make the economy competitive again (Nurmandi and Purnomo, 2011). As a result, the impact on the economy is not very pronounced in a pandemic situation.

Figure 1. Positive Trends and Mortality Rates of the COVID-19 Pandemic per Day in Indonesia

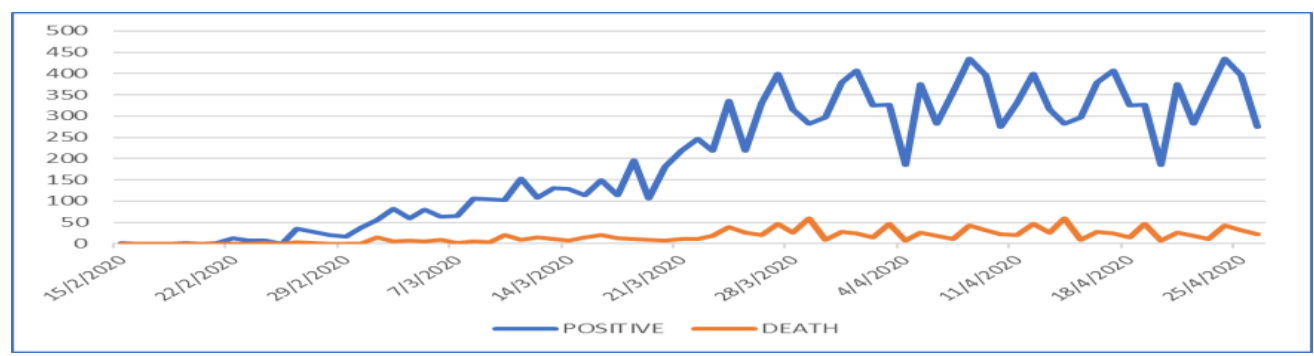

Source: Own Research, 2020. 
The COVID 19 case shows how severe paralysis occurs in the economy sector of an infected country (Rincón-Aznar, Mao, and Tong, 2020). The pandemic in China becomes a clear example that the threat of COVID-19 puts high pressure on social and economic aspects. Various attempts are made to reduce the spread of COVID19, such as quarantine and widespread restrictions on mobility and work travel. Instead, those efforts result in new problems in unpredictable delays in the movement of the economic sector in the country. Thus, it has a significant reduction effect in many service sector activities (Ataguba, 2020). In addition, other adverse consequences of the spread of the COVID-19 pandemic in the economic aspects also arise, such as direct disruption to the global supply chain, weaker demand for imported goods and services, and a broader decline in the international tourism sector and business travel (Karabulut et al., 2020). Thus, at the peak of the pressures that cause the economic cessation duration is quite long and unpredictable, increasing unemployment becomes more vulnerable due to lack of productivity and excessive spending on maintenance (Kantamneni, 2020).

The high-level spread of COVID-19 to various countries is unavoidable, including Indonesia. Figure 1 explains that the COVID-19 pandemic in Indonesia began in mid-February, which was initially stated that there were two positive cases in the city of Bogor, West Java, after travelling from Malaysia. Then, since February 21, 2020, the development of a positive case of COVID-19 in Indonesia has increased each day significantly. At the end of February until the first week of March, the development of patients who tested positive for COVID-19 reached an average of 50 people per day. The number of COVID-19 cases from the second to third week of March also experienced an increase, reaching above 130 people. Moreover, from the third week until the end of April 2020, the average positive cases of COVID-19 reached above 325 people per day. With a large number of people infected in a short time, many criticisms have emerged from the community to the Government as it considered unable to provide health care or maintain economic functioning. It exacerbates political instability.

It is undeniable that the significant increase in COVID-19 cases is due to policies, which at that time had not yet focused on preventive measures. It then causes an increase in COVID-19 mortality in Indonesia. The data reveal that the COVID-19 mortality rate trend in Indonesia is experiencing an increase and is almost the same, which tends to be a moderate slope. It is undoubtedly influenced by the restriction policy with a positive case trend of COVID-19 until the end of March. In fact, since the first week of the Aril 2020, the development of COVID-19 mortality has a trend of large-scale mobility (PSBB) taken by several government agencies to reduce its spread (Tempo.com, 2020).

The policy on limiting mobility in several sectors taken by the Government certainly had an impact on mobility trends on socio-economic activities. As seen in Figure 2, it shows the development of social-economic activity mobility trends, including the retail and recreation sectors, grocery and pharmacy, parks, transit stations, 
64

workplaces, and residential sectors in Indonesia in the period from February to April. The above data indicate the development of the retail and recreation sector trend since the beginning of the research period in mid-February 2020 has decreased the mobility and increased again at the end of February to mid-March 2020. This condition showed that the increase in COVID-19 cases, which was getting higher at the end of February, caused the population to experience panic and carry out panic buying, especially on retail goods. It also experienced in the grocery and pharmacy sectors. This panic occurs because people's expectations for the future were full of uncertainties. It is undeniable that pandemic also not only has an impact on the economic life of a country but also gives a high impact pressure on the social effects of the communities. Although, panic buying events that occur in the middle of a pandemic event also vary in level based on the category of country and culture that grows in.

Figure 2. Mobility Trend of Economic Activities per Day in Indonesia

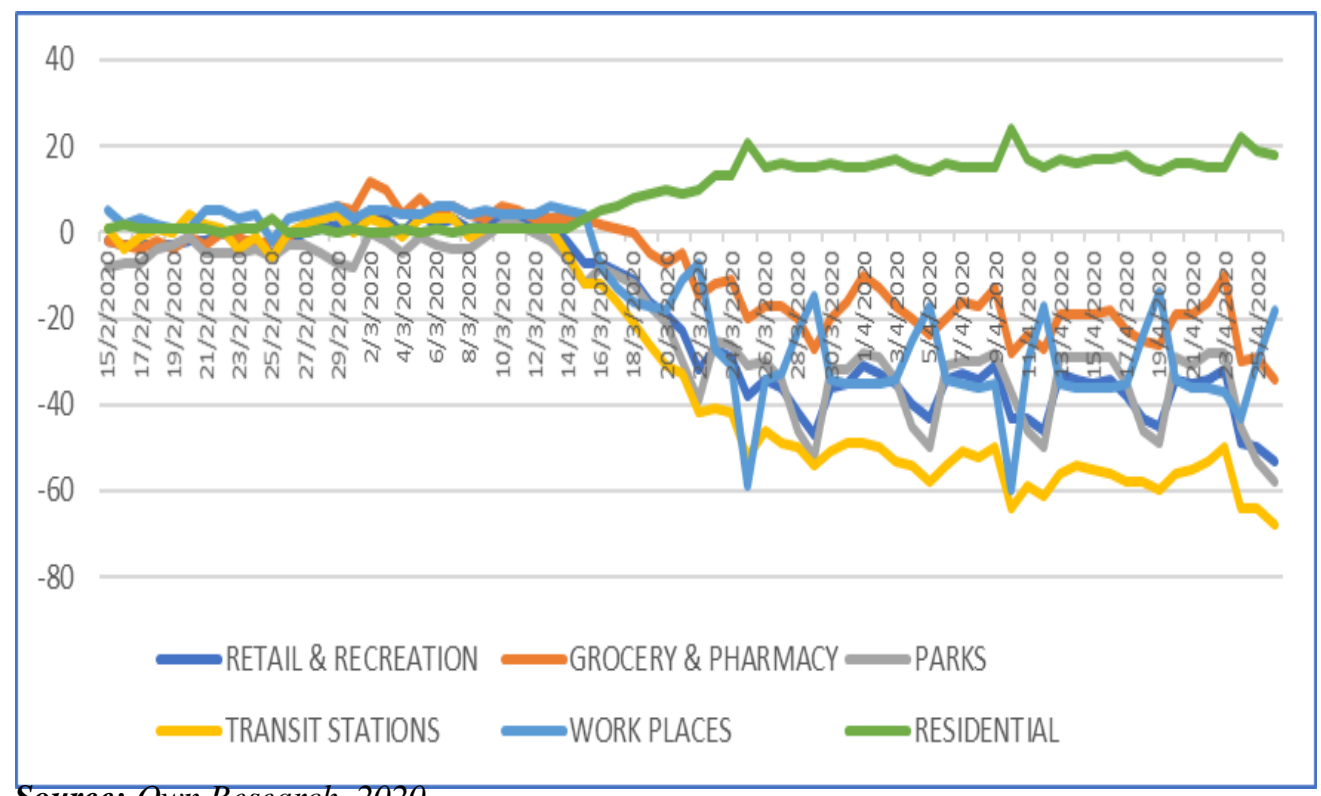

Source: Own Research, 2020.

The panic buying phenomenon has indeed become unavoidable when a pandemic occurs. It also happened in some developed countries like Canada in the early days of the COVID-19 pandemic (Hobbs, 2020). It is undeniable that one of the real impacts of a pandemic outbreak is an intense psychological effect, which becomes a moral panic spreading globally and is accompanied by a feeling of stigma about the end of the pandemic. Moral panic is a feeling of extreme concern about threats seen as the destruction of people's physical or cultural safety (Keane and Neal, 2020). Thus, panic buying phenomena are difficult to avoid during a pandemic because psychologically, individuals will try to protect their families by various means (Smith, 2016). 
In this case, the Government's role becomes essential to reduce the level of public anxiety. Good communication patterns must be carried out by the Government through various mainstream media (Zeitzoff, 2017). The mainstream media maximized in this case is the role of communication media, which is demanded to be able to create conditions that do not provoke misinformation and contribute to unnecessary public panic and produce unwanted responses. It is an important thing to remember at the peak of this panic produces egoism like capitalists, xenophobia and believe in every news item that was seen on social media (Cinelli et al., 2020). Because, in a pandemic situation, hoax information can appear to makes various perspective public and contribute to public panic (Rowbotham et al., 2019). It must be a vital point to Government secure public trust, because to resolve pandemic needs collaboration in all sectors (Reppond and Bullock, 2018). The good information system can be taken by Government as the prevent the hoax information spread on public (Al-Kofahi et al., 2020).

The trend of the mobility of the parks sector showed a significant decrease due to mobility in public parks, city parks, open national parks, prone to COVID-19, and the presence of Government appeals to stay at home (Deti Mega, 2020). On the one hand, the development of the transit station sector trend from Figure 2 shows a fairly high decline compared to other sectors. It is indeed due to restrictions of human movement, causing the sector to fall. On the other hand, the mobility trend of the workplace sector, at first, the mobility was still going on and was positive until midMarch, but entering April, it experienced a reasonably high decline. Besides, it is extremely different compared to the residential mobility trend, which has increased since the COVID-19 emerged in Indonesia. It shows that the rules of stay at home cause mobility in settlements at a high level. Many activities and works are carried out at home. Residents disciplined with the Government's appeal to stay at home. However, it is undeniable that some remain to do activities outside. Moreoer, the development of COVID-19 is fast and spreading throughout the country, even across islands in Indonesia.

\section{Relationship Between COVID-19 Pandemic and Socio-Economic Mobility}

Table 2 is the calculation of the correlation coefficient of COVID-19 on economic mobility in each sector, such as the retail and recreation sector, grocery and pharmacy, parks, transit stations, workplaces and residential areas in Indonesia during the research period. The results of general calculations indicate that the relationship between the number of people tested positive for COVID-19 and economic mobility, with an average correlation coefficient above 0.8 , is higher than the relation between COVID-19 death and socio-economic mobility, with an average correlation coefficient above 0.7 during the research period. It shows the public is susceptible to the information on the number of people who have been positively infected compared to information on death due to COVID-19. 
Table 2. Correlations between COVID-19and Socio-Economic Mobility in Indonesia

\begin{tabular}{|c|c|c|c|c|c|c|c|c|c|}
\hline \multicolumn{2}{|c|}{ Correlations } & POS & DEA & $\mathrm{RR}$ & GP & PRK & TS & WP & RES \\
\hline \multirow[t]{2}{*}{ POS } & $\begin{array}{l}\text { Pearson } \\
\text { Correlation }\end{array}$ & 1 & $.771^{* *}$ & $-.885^{* *}$ & $-.800^{* * *}$ & $-.835^{* *}$ & $-.913^{* *}$ & $-.837^{* *}$ & $.896^{* *}$ \\
\hline & Sig. (2-tailed) & & .000 & .000 & .000 & .000 & .000 & .000 & .000 \\
\hline \multirow[t]{2}{*}{ DEA } & $\begin{array}{l}\text { Pearson } \\
\text { Correlation }\end{array}$ & $.771^{* * *}$ & 1 & $-.715^{* *}$ & $-.663^{* *}$ & $-.688^{* *}$ & $-.711^{* *}$ & $-.612^{* *}$ & $.697^{* * *}$ \\
\hline & Sig. (2-tailed) & .000 & & .000 & .000 & .000 & .000 & .000 & .000 \\
\hline \multirow[t]{2}{*}{$\mathrm{RR}$} & $\begin{array}{l}\text { Pearson } \\
\text { Correlation }\end{array}$ & $-.885^{* *}$ & $-.715^{* * *}$ & 1 & $.969^{* *}$ & $.977^{* *}$ & $.987^{* *}$ & $.858^{* *}$ & $-.964^{* *}$ \\
\hline & Sig. (2-tailed) & .000 & .000 & & .000 & .000 & .000 & .000 & .000 \\
\hline \multirow[t]{2}{*}{ GP } & $\begin{array}{l}\text { Pearson } \\
\text { Correlation }\end{array}$ & $-.800^{* *}$ & $-.663^{* *}$ & $.969^{* *}$ & 1 & $.947^{* *}$ & $.942^{* *}$ & $.803^{* * *}$ & $-.921^{* *}$ \\
\hline & Sig. (2-tailed) & .000 & .000 & .000 & & .000 & .000 & .000 & .000 \\
\hline \multirow[t]{2}{*}{ PRK } & $\begin{array}{l}\text { Pearson } \\
\text { Correlation }\end{array}$ & $-.835^{* *}$ & $-.688^{* *}$ & $.977^{* *}$ & $.947^{* *}$ & 1 & $.945^{* *}$ & $.745^{* *}$ & $-.899^{* * *}$ \\
\hline & Sig. (2-tailed) & .000 & .000 & .000 & .000 & & .000 & .000 & .000 \\
\hline \multirow[t]{2}{*}{ TS } & $\begin{array}{l}\text { Pearson } \\
\text { Correlation }\end{array}$ & $-.913^{* *}$ & $-.711^{* *}$ & $.987^{* *}$ & $.942^{* *}$ & $.945^{* *}$ & 1 & $.902^{* *}$ & $-.982^{* * *}$ \\
\hline & Sig. (2-tailed) & .000 & .000 & .000 & .000 & .000 & & .000 & .000 \\
\hline \multirow[t]{2}{*}{ WP } & $\begin{array}{l}\text { Pearson } \\
\text { Correlation }\end{array}$ & $-.837^{* *}$ & $-.612^{* *}$ & $.858^{* *}$ & $.803^{* *}$ & $.745^{* *}$ & $.902^{* *}$ & 1 & $-.956^{* *}$ \\
\hline & Sig. (2-tailed) & .000 & .000 & .000 & .000 & .000 & .000 & & . 000 \\
\hline \multirow[t]{2}{*}{ RES } & $\begin{array}{l}\text { Pearson } \\
\text { Correlation }\end{array}$ & $.896^{* *}$ & $.697^{* * *}$ & $-.964^{* *}$ & $-.921^{* *}$ & $-.899^{* *}$ & $-.982^{* *}$ & $-.956^{* *}$ & 1 \\
\hline & Sig. (2-tailed) & .000 & .000 & .000 & .000 & . 000 & . 000 & .000 & \\
\hline
\end{tabular}

Source: Own Research, 2020.

The calculation results of the correlation between pandemic variables stated positive for COVID-19, and the mobility of social and economic activities on average had a great relationship. The high activity has become a vital point for the Government because of the spread of the virus, which is diagnosed as susceptible to crowd situation (Sirkeci and Yüceşahin, 2020). The correlation coefficient for retail and recreation was -0.885 , for the variable in the grocery and pharmacy sector was -0.88 , the parks sector was -0.835 , the transit station sector was -0.913 , the workplace sector was $-0,837$, and for the residential sector was 0,896 . The negative coefficient value indicates that all sectors have a trend in the opposite direction, except the residential sector that has a trend in the same direction. It demonstrates that the COVID-19 pandemic has negative impacts on the socio-economic sectors with a strong relationship. When the COVID-19 pandemic increased, the sectors of retail and recreation, grocery and pharmacy, parks, transit stations, workplaces decreased in mobility. It shows a significant decline in the service sector (Venkates, 2020). Whereas, the residential sector experienced an increase in line with the increase in the COVID-19 pandemic. It means that mobility in residential is an option that must be made by the Indonesian people to fight COVID-19. So, this is the right policy to be carried out because it is proven effective in suppressing the spread of COVID-19, even though it has several other effects on socio-economics. It is undeniable that this 
policy is indeed carried out by almost all countries that are struggling to slow the transmission of COVID-19 disease.

Then, the relationship between the COVID-19 pandemic variable, which stated died and the mobility of socio-economic activities in Indonesia, also had a strong relationship. The correlation coefficient value for retail and recreation was -0.715 , for the variable in the grocery and pharmacy sector was -0.683 , the parks sector was -0.668 , the transit station sector was -0.711 , the workplace sector was -0.612 , and the residential sector was 0.697. The relationship between COVID-19 with all these variables was negative, except residential variable. The residential variable that had a positive relationship with implementation of work from home which appeal of all residents to stay at home from their activities, except to go out looking for food, medicines, to hospitals, and including online schools. With this impact, government policies on human life, such as the availability of medicines, food and protective equipment, must be a priority (Luca, Fornaro, and Martin, 2020). The physical distancing policy has been emphasized in Indonesia to reduce the spread of COVID19. Even, Bogor City Government once again extends the period of study at home for students in the city of Bogor from April 13 to May 29 2020. The extension applies to students from the level of formal educational and non-formal educational institutions (Ferry, 2020).

This decline in socio-economic activities has had an impact on people's lives, such as a decline in production, an increase in unemployment, and a decrease in the average income of the community. That is another impact of physical distancing policy. It is because, the industrial sector is also a field that feels a great impact because it is related to important facilities being closed for a long time in many countries. The initial global pandemic scenario saw a Gross Domestic Product fall by $2 \%$ below world benchmarks, $2.5 \%$ for developing countries, and $1.8 \%$ for industrialized countries (Maliszewska, Aaditya, Mattoo, and van der Dominique, 2020). This reduction in production will significantly affect the lives of the population in the country. Therefore, appropriate policies are required to reduce the economic contraction. The policies required are fiscal and monetary policies expansive in the long-term. The macroeconomic policy must move to recovery measures, which usually involve monetary and fiscal stimulus. However, in many developing countries, the stimulus may be less effective because of weak monetary and fiscal transmissions with relatively small multipliers (Loayza and Pennings, 2020).

\section{Conclusions and Recommendations}

The trend of the COVID-19 pandemic has increased significantly, which has impacts on socio-economic mobility in Indonesia. The relationship between the COVID-19 pandemic and socio-economic mobility could be either positive or negative. Negative relationships occurred in the recreation sector, grocery and pharmacy sectors, parks, transit stations, and workplace sectors. However, it had a 
positive relationship with the residential sector, meaning that the higher the rate of spread, the higher the number of people staying at home. This cannot be released the physical distancing policy that has been emphasized in Indonesia to reduce the spread of COVID-19. With the low activity of people, it had impacts on the production sector and reduced the average income of the population. With this impact, government policies relating to human life, such as the availability of medicines, food, and protective equipment health, must be a priority. Then, economic policies increase state expenditure (government expenditure), and tax incentives must be made. Furthermore, monetary policy that can accelerate the increase in production by reducing the cost of production through the cost of capital and reduce energy prices becomes an essential choice.

\section{References:}

Abodunrin, O., Oloye, G. 2020. Coronavirus Pandemic and its Implication on Global Economy. International Journal of Arts, Languages and Business Studies (IJALBS), 4.

Al-Kofahi, M.K., Hassan, H., Mohamad, R., Intan, T.P., Com, M. 2020. Information Systems Success Model: A Review of Literature. International Journal of Innovation, Creativity and Change, 12. Retrieved from: www.ijicc.net.

Ali, I., Alharbi, O.M.L. 2020. COVID-19: Disease, Management, Treatment, and Social Impact. Science of the Total Environment, 728, 138861. https://doi.org/10.1016/j.scitotenv.2020.138861.

Alvarez, F., Argente, D., Lippi, F. 2020. A Simple Planning Problem for COVID-19 Lockdown. The National Bureau of Economic Research. https://doi.org/10.3386/w26981.

Arafat, S.M.Y., Kar, S.K., Marthoenis, M., Sharma, P., Apu, E.H., Kabir, R. 2020. Psychological Underpinning of Panic Buying during Pandemic (COVID-19). Psychiatry Research, 113061. https://doi.org/10.1016/j.psychres.2020.113061.

Ataguba, J.E. 2020. COVID-19 Pandemic, a War to Be Won: Understanding its Economic Implications for Africa. Applied Health Economics and Health Policy. https://doi.org/10.1007/s40258-020-00580-X.

Baker, S., Bloom, N., Davis, S., Terry, S. 2020. COVID-Induced Economic Uncertainty. Journal of Chemical Information and Modeling, 53. http://www.nber.org/papers/w26983.pdf.

Barrot, J.N., Grassi, B., Sauvagnat, J. 2020. Sectoral Effects of Social Distancing. SSRN Electronic Journal. https://doi.org/10.2139/ssrn.3569446.

Bartik, A., Bertrand, M., Cullen, Z., Glaeser, E., Luca, M., Stanton, C. 2020. How Are Small Businesses Adjusting to COVID-19? Early Evidence from a Survey. The National Bureau of Economic Research. https://doi.org/10.3386/w26989.

Barua, S. 2020. Understanding Coronanomics: The Economic Implications of the Coronavirus (COVID-19) Pandemic. SSRN Electronic Journal. https://doi.org/10.2139/ssrn.3566477.

Basuki, A.G, Prawoto, N. 2016. Statistik Untuk Ekonomi Dan Bisnis. Yogyakarta, Penerbit Ombak.

Becker, C.M. 1990. The Demo-Economic Impact of the AIDS Pandemic in Sub-Saharan Africa. World Development, 18(12), 1599-1619. https://doi.org/10.1016/0305750X(90)90058-6.

Bento, A.I., Nguyen, T., Wing, C., Lozano-Rojas, F., Ahn, Y.Y., Simon, K. 2020. Evidence 
from Internet Search Data Shows Information-Seeking Responses to News of Local COVID-19 Cases. Proceedings of the National Academy of Sciences of the United States of America. https://doi.org/10.1073/pnas.2005335117

Carter, P., Anderson, E.M. 2020. Health system, public health, and economic implications of managing COVID-19 from a cardiovascular perspective. Eropan Heart Journal. Retrieved from https://academic.oup.com/eurheartj/advancearticle/doi/10.1093/eurheartj/ehaa342/5823766.

Chakraborty, I., Maity, P. 2020. COVID-19 Outbreak: Migration, Effects on Society, Global Environment and Prevention. Science of the Total Environment, 728, 138882. https://doi.org/10.1016/j.scitotenv.2020.138882.

Chan, A.K.M., Nickson, C.P., Rudolph, J.W., Lee, A., Joynt, G.M. 2020. Social Media for Rapid Knowledge Dissemination: Early Experience from the COVID-19 Pandemic. Anaesthesia. https://doi.org/10.1111/anae.15057.

Cinelli, M. Quattrociocchi, W., Galeazzi, A., Valensise, C.M., Brugnoli, E., Schmidt, A.L., Scala, A. 2020. The COVID-19 Social Media Infodemic. Retrieved from: http://arxiv.org/abs/2003.05004.

Del Rio-Chanona, R.M., Mealy, P., Pichler, A., Lafond, F., Farmer, D. 2020. Supply and demand shocks in the COVID-19 pandemic: An industry and occupation perspective. The National Bureau of Economic Research. Retrieved from: http://arxiv.org/abs/2004.06759.

Deti Mega, P. 2020. Disiplinkan ‘Social Distancing’ Dinilai Perlu Regulasi Dan Sanksi. Kompas.com. Retrieved from: https://nasional.kompas.com/read/2020/03/20/19280631/disiplinkan-social-distancingdinilai-perlu-regulasi-dan-sanksi.

Fernandes, N. 2020. Economic Effects of Coronavirus Outbreak (COVID-19) on the World Economy. SSRN Electronic Journal. https://doi.org/10.2139/ssrn.3557504.

Ferry, S. 2020. Pemkot Bogor Perpanjang Belajar Dari Rumah Hingga 29 Mei 2020. CNBCIndonesia.com. Retrieved from: https://www.cnbcindonesia.com/news/20200408201314-4-150728/pemkot-bogorperpanjang-belajar-dari-rumah-hingga-29-mei-2020.

Filipe, J.A. 2020. Epidemics and Pandemics: Covid-19 and the "'Drop of Honey Effect"” International Journal of Economics and Business Administration, VIII, 2, 240-249. https://www.ijeba.com/journal/456.

Gershon, D., Lipton, A., Levine, H. 2020. Managing COVID-19 Pandemic without Destructing the Economy. Retrieved from: http://arxiv.org/abs/2004.10324.

Grima, S., Dalli-Gonzi, R., Thalassinos, I.E. 2020. The impact of COVID-19 on Malta and its Economy and Sustainable Strategies. http://ssrn.com/abstract=3644833.

Guan, Y., Deng, H., Zhou, X. 2020. Understanding the Impact of the COVID-19 Pandemic on Career Development: Insights from Cultural Psychology. Journal of vocational behavior, 103438. https://doi.org/10.1016/j.jvb.2020.103438.

Guerrieri, V., Lorenzoni, G., Straub, L., Werning, I. 2020. Macroeconomic Implications of COVID-19: Can Negative Supply Shocks Cause Demand Shortages? SSRN Electronic Journal. https://doi.org/10.3386/w26918.

Hall, C.M., Scott, D., Gössling, S. 2020. Pandemics, Transformations and Tourism: Be Careful What You Wish For. Tourism Geographies, 1-22. https://doi.org/10.1080/14616688.2020.1759131.

Hien, L., et al. 2020. Positive Impact of Lockdown in Wuhan on Containing the COVID-19 Outbreak in China. Journal of Travel Medicine. Retrieved from: https://academic.oup.com/jtm/advance-article/doi/10.1093/jtm/taaa037/5808003. 
Hobbs, J.E. 2020. Food Supply Chains during the COVID-19 Pandemic. Canadian Journal of Agricultural Economics/Revue canadienne d'agroeconomie: cjag.12237. https://doi.org/10.1111/cjag.12237.

Hossain, M.S., Ferdous, S., Siddiqee, H.M. 2020. Mass Panic during Covid-19 Outbreak- A Perspective from Bangladesh as a High-Risk Country. Journal of Biomedical Analytics 3(2), 1-3. https://doi.org/10.30577/jba.v3i2.40.

Huang, Y., Lin, C., Wang, P., Xu, Z.. 2020. Saving China from the Coronavirus and Economic Meltdown: Experiences and Lessons. SSRN Electronic Journal. https://doi.org/10.2139/ssrn.3570696.

Inoue, H., Todo, Y. 2020. The Propagation of the Economic Impact through Supply Chains: The Case of a Mega-City Lockdown against the Spread of COVID-19. SSRN Electronic Journal. https://doi.org/10.2139/ssrn.3564898.

Jasper, C., Nicomedes, R.M.A.A. 2020. An Analysis on the Panic of Filipinos During COVID-19 Pandemic in the Philippines. Journal of Economic Studies. https://doi.org/10.13140/RG.2.2.17355.54565.

Kantamneni, N. 2020. The Impact of the COVID-19 Pandemic on Marginalized Populations in the United States: A Research Agenda. Journal of vocational behavior, 103439. https://doi.org/10.1016/j.jvb.2020.103439.

Karabulut, G., Bilgin, M.H., Demir, E., Doker, A.C. 2020. How Pandemics Affect Tourism: International Evidence. SSRN Electronic Journal. https://doi.org/10.2139/ssrn.3579530.

Karin, O., Bar-On, Y.M., Milo, T., Katzir, I., Mayo, A., Korem, Y., Alon, U. 2020. Adaptive Cyclic Exit Strategies from Lockdown to Suppress COVID-19 and Allow Economic Activity. Journal medRxiv. https://doi.org/10.1101/2020.04.04.20053579.

Keane, M., Neal, T. 2020. Consumer Panic in the COVID-19 Pandemic. Center for Economic Policy Research. Retrieved from https://papers.ssrn.com/sol3/papers.cfm?abstract_id=3600018Discussion Papers.

Khoury, R., Karam, G. 2020. Impact of COVID-19 on Mental Healthcare of Older Adults: Insights from Lebanon (Middle East). International Psychogeriatrics, 1-8. https://doi.org/10.1017/s104161022000068x.

Kramer, A., Kramer, K.Z. 2020. The potential impact of the Covid-19 pandemic on occupational status, work from home, and occupational mobility. Journal of Vocational Behavior, 103442. https://doi.org/10.1016/j.jvb.2020.103442.

Loayza, N.V., Pennings, S. 2020. Macroeconomic Policy in the Time of COVID-19. In Macroeconomic Policy in the Time of COVID-19. https://doi.org/10.1596/33540.

Luca, F., Martin, W. 2020. Covid-19 Coronavirus and Macroeconomic Policy. SSRN Electronic Journal. Retrieved from https://ssrn.com/abstract=3600018.

Malawani, A.D., Nurmandi, A., Purnomo, P.E., Rahman, T. 2020. Social media in aid of post disaster management. Transforming Government: People, Process and Policy 14(2), 237-260. https://doi.org/10.1108/TG-09-2019-0088.

Maliszewska, M., Aaditya, Mattoo, A., Dominique van der, M. 2020. The Potential Impact of COVID-19 on GDP and Trade. SSRN Electronic Journal. Retrieved from: https://papers.ssrn.com/sol3/papers.cfm?abstract_id=3573211.

McKee, M., Stuckler, D. 2020. If the world fails to protect the economy, COVID-19 will damage health not just now but also in the future. Nature Medicine, 26, 640-642. https://doi.org/10.1038/s41591-020-0863-y.

Nurmandi, A., Purnomo, E.P. 2011. Making the strategic plan work in local government: A case study of strategic plan implementation in yogyakarta special province (ysp). International Review of Public Administration, 16(2), 143-164. 
https://doi.org/10.1080/12264431.2011.10805200.

Ozili, P.K., Arun, T. 2020. Spillover of COVID-19: Impact on the Global Economy. SSRN Electronic Journal. https://doi.org/10.2139/ssrn.3562570.

Purnomo, E.P., Ramdani, R., Agustiyara, Q., Tomaro, V.P., Samidjo, G.S. 2019. Land ownership transformation before and after forest fires in Indonesian palm oil plantation areas. Journal of Land Use Science 14(1), 37-51. https://doi.org/10.1080/1747423X.2019.1614686.

Raju, B. 2020. A Study on Indian Mathematicians and their Contributions Covered in NCERT Mathematics text books. Studies in Indian Place Names, 40(69), 1795.

Reppond, H.A., Bullock, H.E. 2018. Framing Homeless Policy: Reducing Cash Aid as a Compassionate Solution. Analyses of Social Issues and Public Policy, 18(1), 284-306. https://doi.org/10.1111/asap.12156.

Rincón-Aznar, A., Mao, X., Tong, M. 2020. Global Value Chains and Economic Dislocations. National Institute Economic Review, 252, R1-R3. https://doi.org/10.1017/nie.2020.13.

Rowbotham, S., McKinnon, M., Marks, L., Hawe, P. 2019. Research on media framing of public policies to prevent chronic disease: A narrative synthesis. Social Science and Medicine, 237, 112428. https://doi.org/10.1016/j.socscimed.2019.112428.

Sharif, A., Aloui, C., Yarovaya, L. 2020. COVID-19 Pandemic, Oil Prices, Stock Market and Policy Uncertainty Nexus in the US Economy: Fresh Evidence from the WaveletBased Approach. SSRN Electronic Journal. https://doi.org/10.2139/ssrn.3574699.

Sim, K., Chua, H.C., Vieta, E., Fernandez, G. 2020. The anatomy of panic buying related to the current COVID-19 pandemic. Psychiatry Research, 288, 113015. https://doi.org/10.1016/j.psychres.2020.113015.

Sirkeci, I., Yüceşahin, M. 2020. Coronavirus and Migration: Analysis of Human Mobility and the Spread of COVID-19. Ceeol.Com, 17(2), 379-398. https://doi.org/10.33182/ml.v17i2.935.

Smith, K. 2016. Morrison to blame for panic buying over COVID-19. Green Left Weekly, (1100), 4.

Sugiyono. 2012. Metode Penelitian Kuantitatif Kualitatif dan R\&D. In Alfabeta. Bandung.

Tempo.com. 2020. Pembatasan Jumlah Penumpang Pesawat Mulai Berlaku - Laporan Utama - koran.tempo.co. Retrieved from: tempo.com website: https://koran.tempo.co/read/laporan-utama/451893/pembatasan-jumlah-penumpangpesawat-mulai-berlaku?

Venkates, N.S. 2020. View of the Impact of a Corona-19 Pandemic on Indian Economy. UGC Care Journal. Retrieved from https://www.purakala.com/index.php/09712143/article/view/853/767.

Walmsley, T., Rose, A., Wei, D. 2020. Impacts on the U.S. Macroeconomy of Mandatory Business Closures in Response to the COVID-19 Pandemic. SSRN Electronic Journal. https://doi.org/10.2139/ssrn.3570117.

Zeitzoff, T. 2017. How Social Media Is Changing Conflict. Journal of Conflict Resolution, 61(9), 1970-1991. https://doi.org/10.1177/0022002717721392. 